\title{
Propagation of bovine spermatogonial stem cells in vitro
}

\author{
Pedro M Aponte ${ }^{1,2}$, Takeshi Soda ${ }^{1}$, Katja J Teerds ${ }^{3}$, S Canan Mizrak ${ }^{4}$, Henk J G van de Kant ${ }^{1}$ \\ and Dirk G de Rooij ${ }^{1,4}$ \\ ${ }^{1}$ Departments of Endocrinology and Metabolism, Faculty of Science, Utrecht University and of Cell Biology, UMCU, \\ $3584 \mathrm{CH}$ Utrecht, The Netherlands, ${ }^{2}$ Department of Biomedical Sciences, Faculty of Veterinary Sciences, Central \\ University of Venezuela, Aragua State, PO Box 4563, Maracay, Venezuela, ${ }^{3}$ Department of Animal Sciences, \\ Wageningen University, 6709 PJ Wageningen, The Netherlands and ${ }^{4}$ Center for Reproductive Medicine, Academic \\ Medical Hospital, 1105 AZ Amsterdam, The Netherlands
}

Correspondence should be addressed to P M Aponte; Email: apontep@gmail.com

\begin{abstract}
The access to sufficient numbers of spermatogonial stem cells (SSCs) is a prerequisite for the study of their regulation and further biomanipulation. A specialized medium and several growth factors were tested to study the in vitro behavior of bovine type A spermatogonia, a cell population that includes the SSCs and can be specifically stained for the lectin Dolichos biflorus agglutinin. During short-term culture ( 2 weeks), colonies appeared, the morphology of which varied with the specific growth factor(s) added. Whenever the stem cell medium was used, round structures reminiscent of sectioned seminiferous tubules appeared in the core of the colonies. Remarkably, these round structures always contained type A spermatogonia. When leukemia inhibitory factor (LIF), epidermal growth factor (EGF), or fibroblast growth factor 2 (FGF2) were added, specific effects on the numbers and arrangement of somatic cells were observed. However, the number of type A spermatogonia was significantly higher in cultures to which glial cell line-derived neurotrophic factor (GDNF) was added and highest when GDNF, LIF, EGF, and FGF2 were all present. The latter suggests that a proper stimulation of the somatic cells is necessary for optimal stimulation of the germ cells in culture. Somatic cells present in the colonies included Sertoli cells, peritubular myoid cells, and a few Leydig cells. A transplantation experiment, using nude mice, showed the presence of SSCs among the cultured cells and in addition strongly suggested a more than 10 000-fold increase in the number of SSCs after 30 days of culture. These results demonstrate that bovine SSC self-renew in our specialized bovine culture system and that this system can be used for the propagation of these cells.

Reproduction (2008) 136 543-557
\end{abstract}

\section{Introduction}

Spermatogonial stem cells (SSCs) have the potential to selfrenew and at the same time generate the cascade of differentiating germ cells that will eventually lead to the formation of sperm. The regulation of the SSC self-renewal process is not yet completely understood. To study the characteristics of SSCs, large enough populations of pure SSCs must be isolated. One way to reach this goal is to propagate these cells in vitro and various attempts to achieve this have been carried out (Aponte et al. 2005).

Interestingly, using a combination of growth factors and a special stem cell medium, Kanatsu-Shinohara et al. $(2003 b)$, by way of continuous subculturing during 4-5 months, could achieve an expansion of mouse SSCs in the order of $10^{12}$-fold. Kubota et al. (2004b) also induced SSC renewal in a serum-free culture system based on a mitotically inactivated feeder layer and showed that the combination of glial cell line-derived neurotrophic factor (GDNF), soluble receptor for GDNF (GFR $\alpha 1)$, and fibroblast growth factor 2 (FGF2) was best to induce self-renewal. In both these systems, SSCs were found to form colonies. When the cells of these colonies were enzymatically dispersed and replated, their constituent SSCs could start new colonies.

Colonies also appeared when bovine SSCs were grown on top of a Sertoli cell monolayer (Oatley et al. 2004, Aponte et al. 2006). In this system, the colonies appeared to be the result of complex interactions between SSCs and Sertoli cells (Oatley et al. 2004, Aponte et al. 2006). These colonies were also able to regenerate new colonies upon subculturing (Izadyar et al. 2003a). When adding GDNF, a member of the transforming growth factor- $\beta$ superfamily, to these cultures, type A spermatogonia in the culture increased in number (Aponte et al. 2006). Moreover, SSC numbers increased twofold when compared with controls after 1 week of culture under the influence of GDNF (Oatley et al. 2004, Aponte et al. 2006).

After transplantation of a germ cell suspension into the seminiferous tubules of a recipient mouse testis, the SSCs among the transplanted germ cells migrate to the basal membrane of the seminiferous tubules and subsequently start to form a repopulating colony of donor 
spermatogenesis. In this colony at first, stem cell renewal will prevail (van Beek et al. 1990) but then also differentiating spermatogonia and subsequent germ cell types will be formed (Brinster \& Avarbock 1994, Brinster \& Zimmermann 1994). However, because of the large phylogenetic distance between mouse and bovine, only type A spermatogonia are formed in the colonies originating from the bovine SSCs in the recipient mouse testis (Izadyar et al. 2003a). With time, the colonies grow along the length of the seminiferous tubules. One SSC will only give rise to one repopulating colony and when, as in this study, relatively few SSCs are transplanted very few if any donor SSCs will by chance seed in the same area and produce overlapping colonies. The more SSCs are transplanted the more colonies will be formed. With time, in each of these colonies the founding SSCs will give rise to more and more progeny, in the present experiment consisting of new SSCs (which are also type A spermatogonia) and type A spermatogonia that are at the beginning of the differentiation pathway. Therefore, in each transplanted mouse testis, the total number of bovine type A spermatogonia will be directly related to the number of originally transplanted bovine SSCs.
In the present study, we tested a specific stem cell culture medium and various growth factors for their effects on qualitative and quantitative aspects of bovine SSC behavior in vitro. In particular, we studied the cellular composition of the colonies formed in culture and estimated changes in SSC numbers using the transplantation assay. The results indicate that bovine SSCs can be successfully propagated in culture, a crucial step in the stem cell technology field that will most likely impact the cattle industry.

\section{Results}

\section{Colony formation}

All cultures started with a mixed population of cells including bovine type A spermatogonia and somatic cells. The percentage of contamination with somatic cells was about $60 \%$ after differential plating, and then dropping to $30 \%$ after Percoll discontinuous gradient centrifugation. Colonies formed locally in some areas of the culture plate. The colony-forming cells in the initial suspension, including both somatic and germ cells, approached each other and became tightly packed as the colonies continued to grow during their development (Fig. 1A-D).
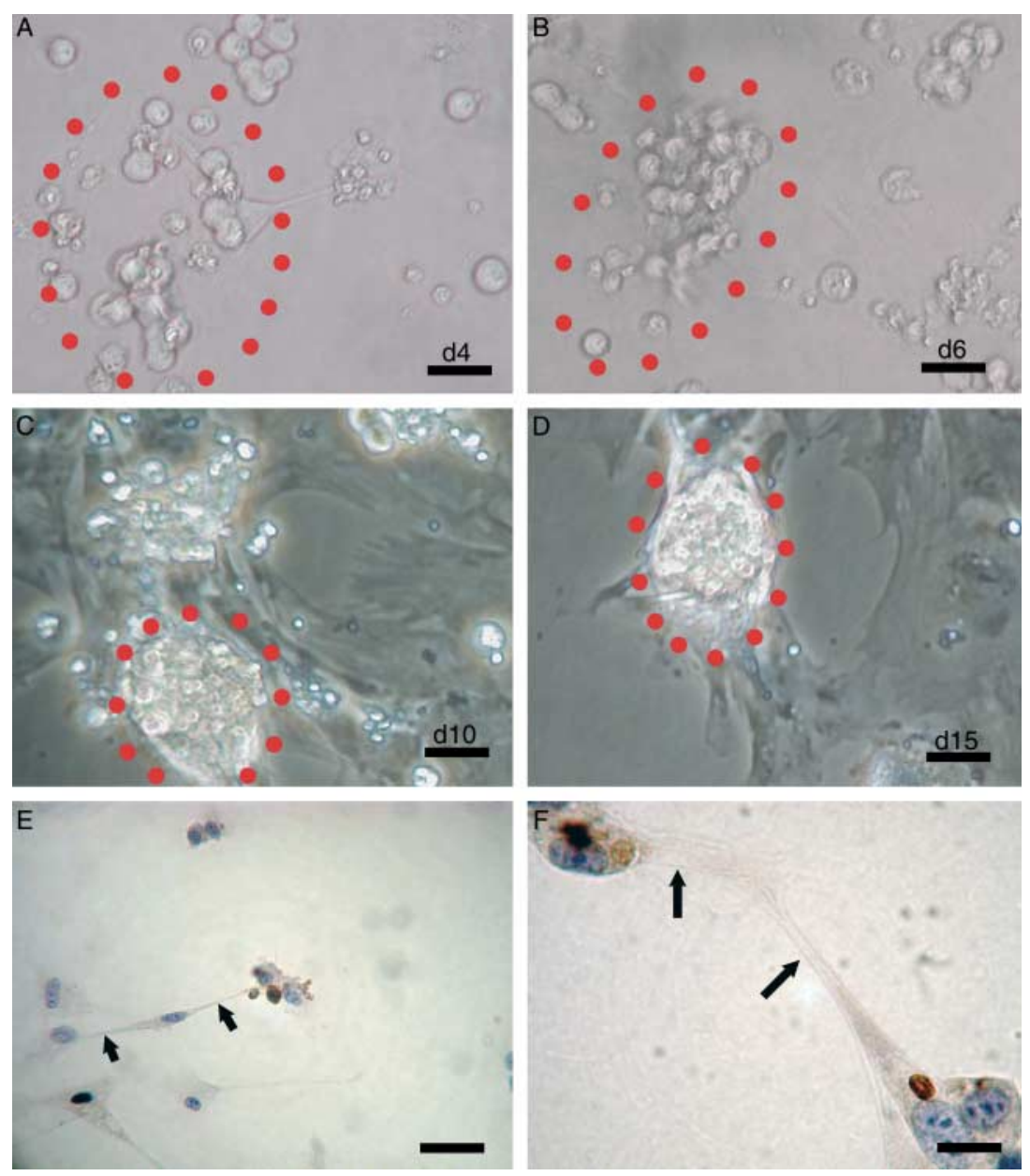

Figure 1 Typical development of colonies during short-term culture in supplemented MEM medium without growth factors. (A-D) Serial microphotographs of one area of the culture plate showing the development of one bovine germ cell-somatic cell colony during short-term culture; $\mathrm{d} 4, \mathrm{~d} 6, \mathrm{~d} 10$, and d15 are days 4, 6, 10, and 15 respectively. Red dots encircle the cells involved in the formation of the colony shown. Nomarski optics. Bar $=20 \mu \mathrm{m}$. (E) Cytoplasmic extensions (arrows) of one somatic cell reaching a small group of colony-forming type $A$ spermatogonia. Bar $=25 \mu \mathrm{m}$. (F) Cytoplasmic extensions (arrows) of type A spermatogonia contacting each other within a forming colony. Bar $=10 \mu \mathrm{m}$. (E) and (F) were obtained from 4-day culture plates immunostained for DBA (brown) and counterstained with Mayer's hematoxylin (blue). DBA (brown) joins carbohydrates at the Golgi system of type A spermatogonia (Ertl \& Wrobel 1992). The process of colony formation that took place using MEM medium was similar to other treatments involving the use of stem cell medium. 
This behavior was regardless of the treatment. Between days 7 and 15 of culture, the colonies grew about sevenfold in volume independently of the treatment. Colonies appeared de novo and not as a result of cells detaching or the monolayer folding upon confluency. Some somatic cells formed the monolayer while some others committed to colony formation. Cytoplasmic extensions from peripherally located somatic cells in the colonies connected with nearby germ cells at the time colonies could be observed for the first time (Fig. 1E). Type A spermatogonia also showed contacting cytoplasmic extensions (Fig. 1F).

The growth of the colonies seemed to occur preferentially at the outskirts of the colonies, since in these areas many somatic cells showed mitotic figures (Fig. 2E). As development progressed, the colonies remained attached to the underlying monolayer by a stalk. Thus, once formed, colonies maintain a short physical connection with the monolayer. This became evident pulling out the colonies for histological processing. Additionally, in some sectioned colonies, part of the broken stalk could be seen to be made up of cells similar to those in the monolayer.

\section{Comparison of cultures in supplemented minimum essential medium (MEM) and stem cell medium}

A specialized stem cell medium was used, based on a hematopoietic stem cell proprietary medium with several enrichments (Kanatsu-Shinohara et al. 2003b). The new stem cell medium outperformed supplemented MEM in terms of number of colonies appearing in culture $(P<0.01)$ and number of Dolichos biflorus agglutinin (DBA)-positive cells, i.e., type A spermatogonia $(P<0.01$; Fig. 3). Consequently, in further experimentation, only the stem cell medium was used.

Colonies appearing in cultures in which supplemented MEM was used were smaller than those with the stem cell medium $\left(0.003 \pm 0.002 \mathrm{~mm}^{3}\right.$ vs $0.024 \pm$ $0.008 \mathrm{~mm}^{3}$ respectively; $\left.P<0.05\right)$. Supplemented MEM colonies showed that many empty intercellular spaces surrounding irregular areas of dead cells and debris where spermatogonia could be seen in scattered patterns (Fig. 2A and B). By contrast, the sections of stem cell medium colonies contained round structures within the core of the colonies (Fig. 2C and D). A three-dimensional
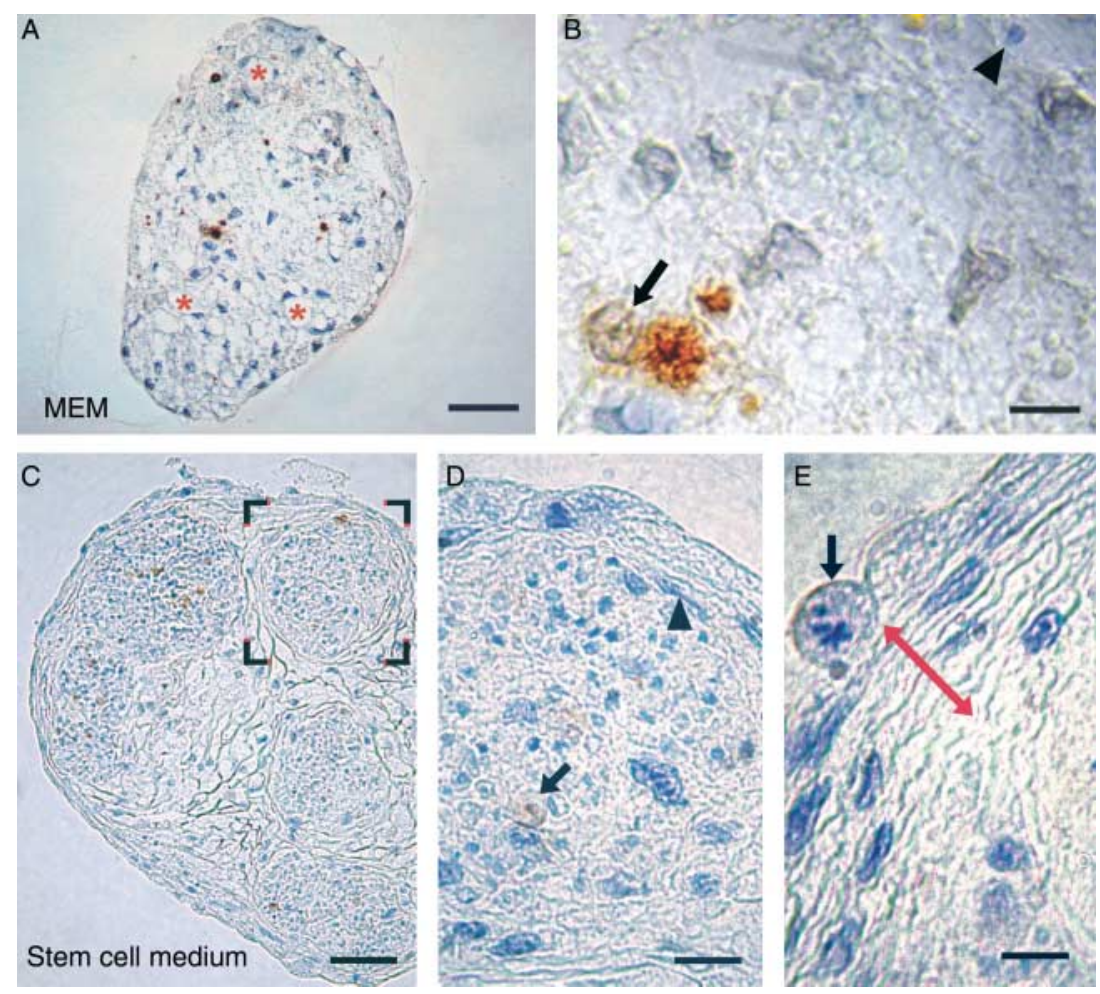

Figure 2 Comparison of two different culture media (MEM versus stem cell medium) on the morphology of bovine spermatogonial cultures after 15 days. All images originate from histological sections of colonies immunostained for DBA (brown) and counterstained with Mayer's hematoxylin (blue). (A and B) MEM (MEM refers to supplemented MEM, see Materials and Methods). (C-E) Stem cell medium. (A) MEM colonies were smaller in size when compared with colonies appearing with stem cell medium and showed wide intercellular spaces and even lacunae in the core of the colonies $(*)$. Bar $=85 \mu \mathrm{m}$. (B) MEM colonies showed numerous pycnotic nuclei (arrowheads) among normal looking type A spermatogonia (big round nucleous with one large central nucleolus) (arrows). Bar $=15 \mu \mathrm{m}$. (C) With the stem cell specialized medium, areas resembling round crosssections of seminiferous tubules are formed inside the colonies (one example in framed area). Notably, no such structures were seen in colonies arising using supplemented MEM. Bar $=200 \mu \mathrm{m}$. (D) Type A spermatogonia were always located inside the round areas (arrow). These areas had surrounding layers of somatic flattened cells (arrowhead). Bar $=20 \mu \mathrm{m}$. (E) The colonies had an outer capsule made up of somatic flattened cell layers (red double head arrow) which showed evidence of proliferation as mitotic figures were seen (arrow). Bar $=15 \mu \mathrm{m}$. 

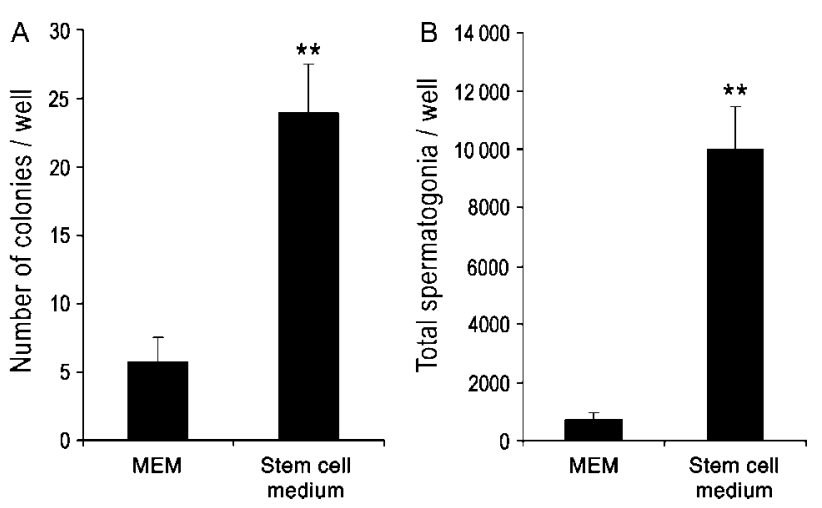

Figure 3 Comparison of the effect of two different culture media (supplemented MEM versus stem cell medium) on the formation of colonies in bovine spermatogonial cultures. (A) Number of colonies per $2 \mathrm{~cm}^{2}$ well after 15 days of culture $(* * P<0.01)$. (B) Absolute number of DBA (Dolichos biflorus agglutinin)-positive bovine type A spermatogonia in colonies as estimated by stereological methods. MEM refers to supplemented MEM (see Materials and Methods). The results are presented as the mean \pm s.E.M. of three independent experiments $\left({ }^{* *} P<0.01\right)$.

reconstruction of these round structures would most likely render a cyst. Cross-sections of these structures were round with clear sharp boundaries organized by flat somatic cells, morphologically similar to peritubular myoid cells. Interestingly, the DBA-positive type A spermatogonia were always within the boundaries of these structures. Most other somatic cells remained outside of the round structures, forming the bulk of the colonies (Fig. 2C). Overall, in the stem cell medium, the somatic cell areas had a higher cell density than in the supplemented MEM colonies.

To learn more about the nature of the somatic cells in culture, immunohistochemistry was carried out using $\alpha$-smooth muscle actin ( $\alpha$-SMA) as a marker for peritubular myoid cells, vimentin as a marker for Sertoli cells, and $3 \beta$-hydroxysteroid dehydrogenase (HSD) type 1 to detect Leydig cells. Indeed in sections of bovine testes, the antibodies against $\alpha$-SMA, vimentin, and $3 \beta$-HSD detected peritubular myoid cells, Sertoli cells, and Leydig cells respectively (Fig. 4E-G). In cultures, immunohistochemistry for $\alpha$-SMA showed reaction primarily at the outskirts of the colonies with some positive cells scattered through the colonies, but only occasionally within the round structures (Fig. 4A and C). Vimentin-positive cells were located also in the outskirts but were more widely spread within the colonies than $\alpha$-SMA-positive cells, especially within the round structures (Fig. 4B and D). Some flat cells circumscribing the round structures were vimentin positive, while a smaller number stained positive for $\alpha$-SMA (Fig. 4C and D).

Immunohistochemical staining for $3 \beta$-HSD type 1 , revealed a few rare Leydig cells in the culture (Fig. $4 \mathrm{H}$ ), their number being less than 1 per 200 cells.

\section{Effect of adding growth factors}

\section{Leukemia inhibitory factor (LIF)}

When LIF was added, the interior of the colonies was similar to that in colonies arising in cultures in stem cell medium only, but the border of the round structures was less defined and the spermatogonia within these areas were lying in a non-characteristic pattern together with many cells with pycnotic nuclei. The round areas were surrounded by several compact, concentric layers of somatic cells with few intercellular empty spaces (Fig. 5A, D and G).

\section{Epidermal growth factor (EGF)}

Under the influence of EGF, the colonies appeared as spherical complexes joined by bridges (Fig. 5B, E and H). These bridges were composed of somatic cells that merged with those present within the spherical units of the colonies. The interior of the colonies was rather spongiform with scattered, ill-defined round structures where spermatogonia could be seen inside. Occasionally, medium to large empty, cyst-like areas could be observed.

\section{FGF2}

Unlike the other growth factors, FGF2 induced the formation of rather large elongated worm-shaped structures, three-dimensional in shape as could be observed through the stereomicroscope. Occasionally, they appeared as the usual spherical colonies. Inside of the colonies, there were also round structures with unclear borders, inside which type A spermatogonia were confined. The surrounding somatic cells showed a very compact arrangement with scarce empty intercellular spaces (Fig. 5C, F and I).

\section{$G D N F$}

In cultures to which GDNF was added, the spherical colonies were formed with large internal round areas with many bovine spermatogonia (DBA positive) with the typical morphology (big round nucleus with one large central nucleolus) inside. In some colony sections, the round areas represented as much as about $50 \%$ of the colony area and were usually located eccentrically (toward the outer limit of the colonies) with scarce surrounding somatic cells (Fig. 6A-C).

\section{LIF, EGF, FGF2, and GDNF}

When cultures were carried out using a combination of the four growth factors, colonies appeared as very large ovoid structures and showed a mixture of characteristics seen when individual growth factors were added (Fig. 6D-H). For instance, large internal round areas commonly placed toward the periphery with many morphologically normal spermatogonia inside with a big 
A
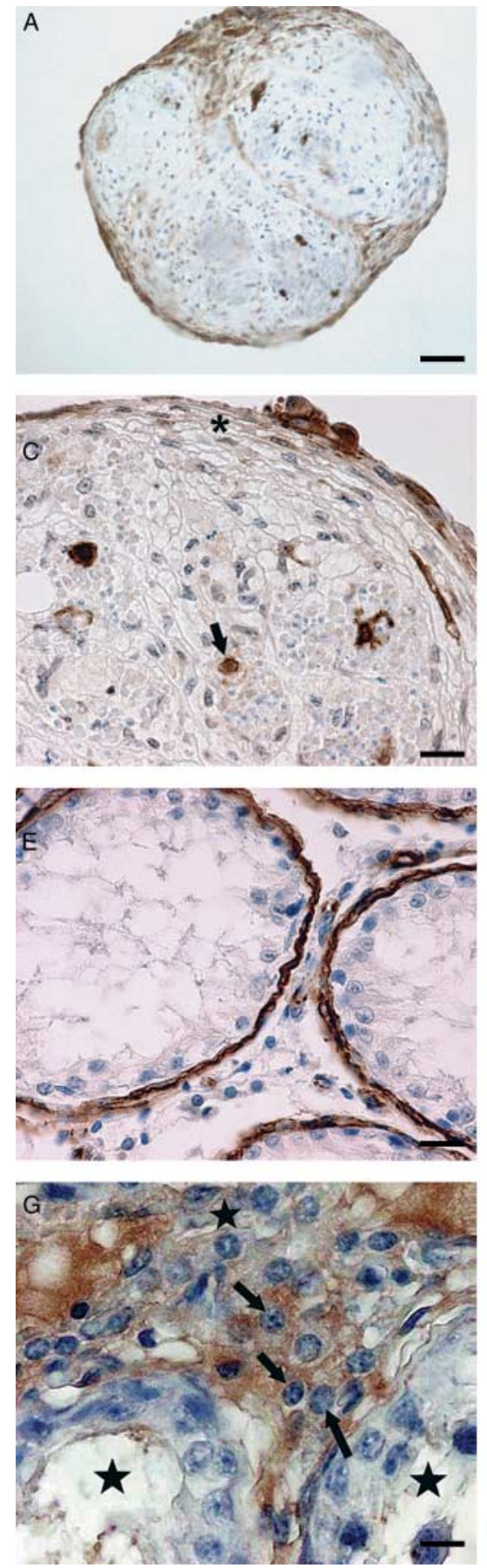
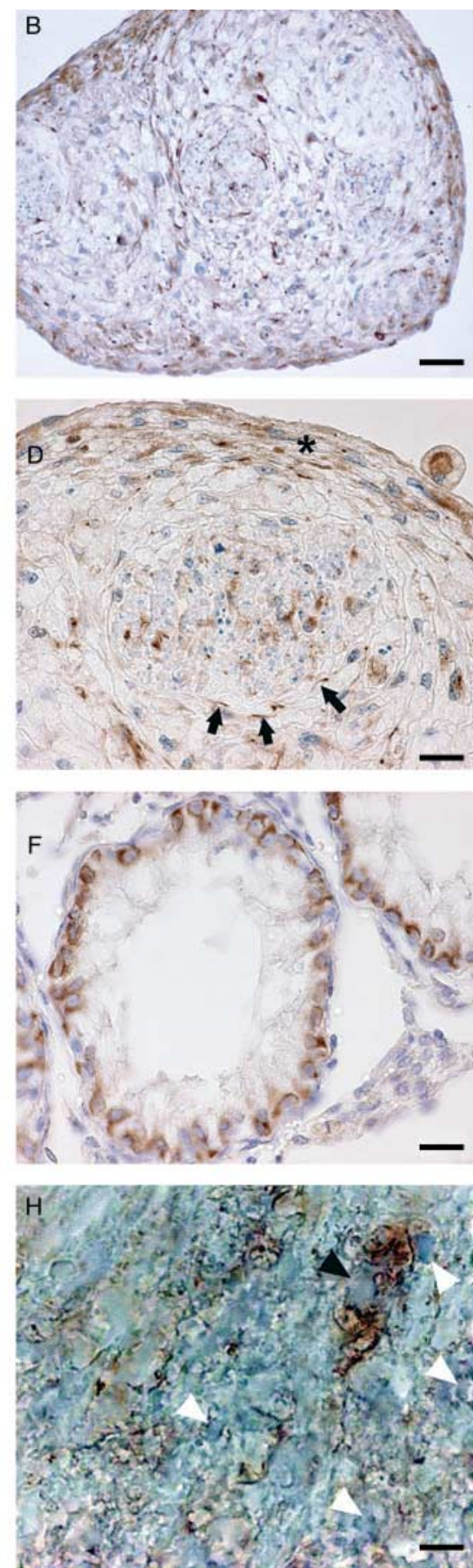

Figure 4 Identification of somatic cells in bovine spermatogonial cultures. (A and B) General pattern of immunostaining (brown) of $\alpha$-smooth muscle actin ( $\alpha$-SMA) (A) and vimentin (B) in histological sections of spermatogonial colonies from 15-dayold cultures and treated with four growth factors (EGF FGF2, LIF, and GDNF). Bar $=80 \mu \mathrm{m}$. (C and D) Details of immunostaining (brown) of $\alpha$-SMA (C) and vimentin (D) of histological sections of the described colonies. Many vimentin and $\alpha$-SMApositive cells are located at the colony outer somatic cell concentric layers $\left({ }^{*}\right)$. Rarely, $\alpha$-SMApositive cells were surrounding round areas resembling cross-sectioned seminiferous tubules (arrow, C) while some surrounding flat cells were vimentin positive (arrows, D). Bar $=40 \mu \mathrm{m}$.

(E) $\alpha$-SMA and (F) vimentin immunostainings of bovine seminiferous tubules showing $\alpha$-SMA is a specific myoid peritubular cell marker. Some endothelial cells of the capillaries in the intersticium stain positive as well; this has been shown to be a specific pattern of staining for bovine species (Devkota et al. 2006) (E, brown), while vimentin specifically marks Sertoli cells within the seminiferous tubules ( $F$, brown). In both panels,

(E) and (F), cross-sections of seminiferous tubules correspond to prepubertal bulls closely after the start of spermatogenesis. Thus, the only germ cells present are a few type A spermatogonia (not stained). Bar $=40 \mu \mathrm{m}$. Immunohistochemical staining for the presence of $3 \beta$-HSD type 1 , a marker for Leydig cells. (G) Pre-pubertal bull testis, $3 \beta$-HSD-positive Leydig cells (arrows) are located in the interstitium surrounded by seminiferous tubules (asterisk). Bar $=13 \mu \mathrm{m}$. (H) Stem cell culture, a contaminating Leydig cell is indicated by a black arrowhead. The surrounding cells are indicated by white arrowheads. Contaminating Leydig cells were rarely observed in the cultures $(<0.5 \%)$. Bar $=6 \mu \mathrm{m}$. All stainings were counterstained with Mayer's hematoxylin (blue). round nucleus and single large nucleolus, as seen with GDNF, but embedded in compact somatic cells with scarce empty intercellular spaces which is typical for cultures to which only FGF2 was added (Fig. 5).

The stereological variable volume density of the round areas (percentage of the total colony volume occupied by round areas) was significantly smaller in the EGFtreated colonies $(17.8 \pm 0.3 \%),(P<0.05)$, than with the rest of the growth factor treatments (range $27.8 \pm 0.7$ to $48.8 \pm 0.7 \%)$.
In general, somatic cell numbers increased during culture. The germ cell:somatic cell ratio changed during culture with the four growth factors from 2.33 (starting cell suspension) to 0.146 .

\section{The effects of growth factors on spermatogonia}

More colonies tended to appear in cultures to which all four growth factors were added, but no statistical significance was found with the different growth factor 

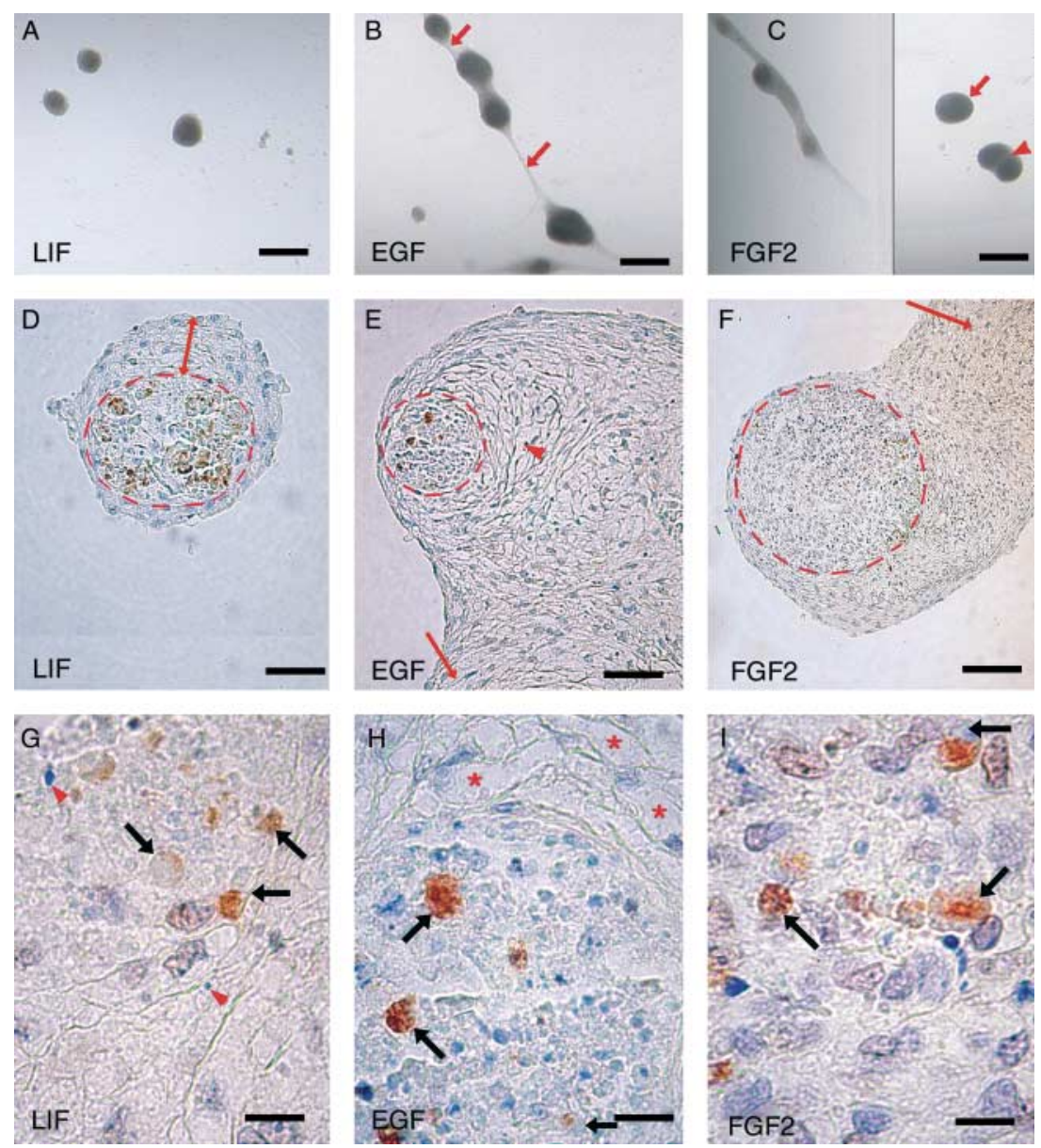

Figure 5 Morphology of colonies appearing under the effect of the growth factors LIF, EGF, or FGF2 (short-term culture, 15 days). (A-C) The general morphology of the colonies. LIF colonies (A) were spherical, while EGF colonies (B) were made up of spheres connected by bridges (arrows) and FGF2 (C) colonies were elongated structures with sometimes single (arrow) or double spheres (arrowhead). (A-C) Bar $=0.5 \mathrm{~mm}$. Sections of colonies were immunostained for DBA (brown) to detect bovine type A spermatogonia. Note that these cells concentrate in round areas resembling round cross-sections of seminiferous tubules in all cases. Counterstaining with Mayer's hematoxylin stained the nuclei of all cells (blue); LIF (D and G), EGF (E and H), FGF2 (F and I). (D-F) Depict the round areas (red outline) in colonies appearing in the presence of LIF, EGF, and FGF2 respectively. LIF colonies (D) had a not well-defined border of the round areas, surrounded by thick layers of concentric somatic cells (red double head arrow). EGF colonies (E) showed empty cystic spaces (arrowhead) and bridge areas were composed solely of somatic cells (red arrow). The elongated parts of FGF2 colonies (F) had no round structures and consisted of somatic cells (red arrow). (D and E) Bar $=50 \mu \mathrm{m}$ and (F) $100 \mu \mathrm{m}$. (G-I) High magnification images that show round areas with type A spermatogonia inside (arrows). With LIF (G), round areas have irregular boundaries and pycnotic nuclei (arrow heads). EGF colonies $(\mathrm{H})$ show lacunae, scattered in the intercellular space in somatic areas $\left(^{*}\right)$. The somatic areas of FGF2 colonies $(\mathrm{I})$ appear very tightly packed with scarce intercellular space. (G-I) Bar $=10 \mu \mathrm{m}$.

treatments (Fig. 7A). When the data were pooled, there were $21.0 \pm 1.6$ colonies/well. Nevertheless, there were significant differences between treatments with respect to the absolute numbers of type A spermatogonia that were found in culture (Fig. 7B). The colonies grown in the presence of all four growth factors contained the highest numbers of spermatogonia after 2 weeks of culture (15 968 \pm 2160 spermatogonia/well), closely followed by GDNF alone (12 $422 \pm 2172$ spermatogonia/well). The groups with only LIF, EGF, or FGF2 had the lowest numbers (range $5268 \pm 1036$ to $7158 \pm$ 1256 spermatogonia/well). Normally, bovine type A spermatogonia have a round- to oval-shaped nucleus with one to three distinct nucleoli. This typical morphology could be observed more often in the colonies grown with a combination of the four growth factors and with GDNF alone.

\section{Bovine type A spermatogonial kinetics during long-term culture}

In order to perform long-term culture experiments, the stem cell medium with four growth factors (LIF, EGF, FGF2, and GDNF) was used because it provided the best maintenance conditions during short-term culture. Besides, the cells were serially subcultured during long-term experiments. The colonies did not form during long-term culture, probably due to the short passaging 

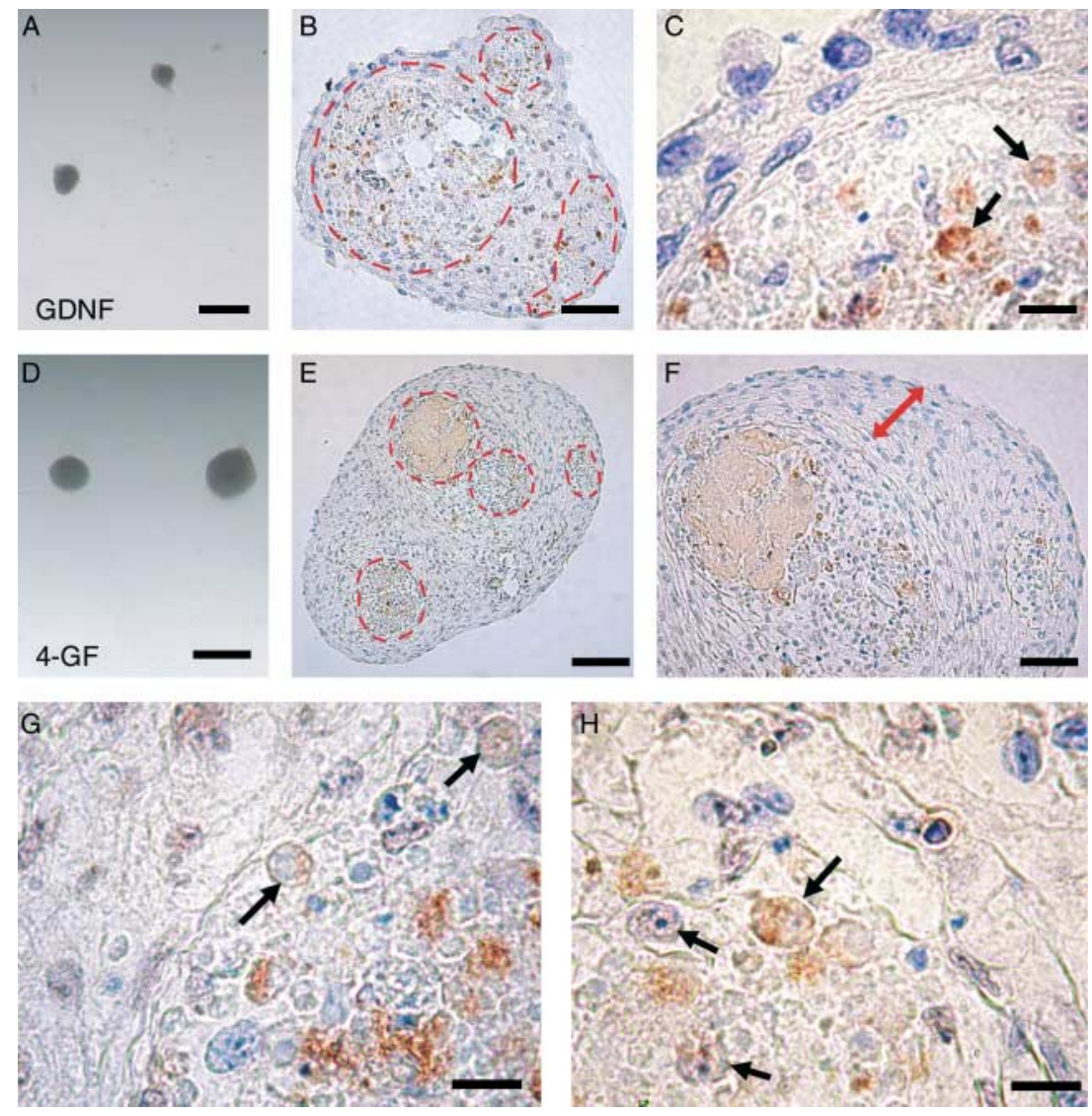

Figure 6 Morphology of colonies appearing under the effect of the growth factors GDNF or a combination of LIF, EGF, FGF2, and GDNF (short-term culture, 15 days). (A and D) The general morphology of the colonies. GDNF colonies (A) were always spherical, while all four growth factors colonies (D) were from spherical to ovoid and were bigger. (A and D) Bar $=0.5 \mathrm{~mm}$. Sections of colonies were immunostained for DBA. DBApositive cells (brown) are type A spermatogonia. They were present in round areas resembling round cross-sections of seminiferous tubules in all cases. Counterstaining with Mayer's hematoxylin stained the nuclei of all cells (blue); GDNF (B and C), all four growth factors (E-H). In GDNF colonies (B), some of the germ cell centers were peripherally located in colonies and represented a very high percentage of the colony bulk (round areas, red outlined). (B) Bar $=50 \mu \mathrm{m}$. (C) A very narrow layer of somatic cells (arrowheads) separated the round areas from the external milieu. Type A spermatogonia are present inside the round areas (arrows). Bar $=10 \mu \mathrm{m}$. (E) Round areas in all four growth factors colonies (red outlined). Note the density of somatic cells, as in FGF2. Bar $=100 \mu \mathrm{m}$. (F) In some areas, there is a thick layer of concentric rings of somatic cells as in LIF (red double head arrow). Also irregular boundaries around round areas can be seen. Bar $=50 \mu \mathrm{m}$. ( $\mathrm{G}$ and $\mathrm{H}$ ). High magnification images of round areas showing the high density of healthy type A spermatogonia (arrows). Bar $=10 \mu \mathrm{m}$.

intervals and ongoing variations of somatic to germ cells ratios. Type $A$ spermatogonial numbers, as determined with the help of the marker DBA, strongly increased during long-term subculturing. In one experiment of 26 days in culture, $\sim 12 \times 10^{6}$ type A spermatogonia were formed from a total starting population of $18 \times 10^{4}$ cells. This growth represented an increment of 365 -fold resulting in what closely resembled an exponential increase with time (Fig. 8A). In correlation with this finding, the cells with the typical morphology of type A spermatogonia could be seen scattered on top of the monolayer up to at least 26 days of culture (Fig. 8B).

\section{Bovine SSC kinetics during long-term culture}

In order to determine whether the SSCs among the type A spermatogonia also increased in the cultures, SSC transplantation was carried out. In the recipient mouse testes, SSCs can home to the basal membrane, proliferate, and start to form a repopulating colony. However, the phylogenetical distance between mice and bovine being too large, no full bovine spermatogenesis was established and only type A spermatogonia were formed (Dobrinski et al. 2000, Izadyar et al. 2003a). The numbers of type $A$ spermatogonia present 2 months after transplantation (DBA-positive cells) were counted and were taken as a measure of the numbers of stem cells transplanted. Mouse type A spermatogonia do not stain for DBA as could be seen in the few areas with endogenous mouse spermatogenesis in irradiated nontransplanted mouse testes nor in normal mouse testes. Spermatogonial transplantation was successfully performed in six animals but unfortunately one died before the end of the experiment (Fig. 8C). 

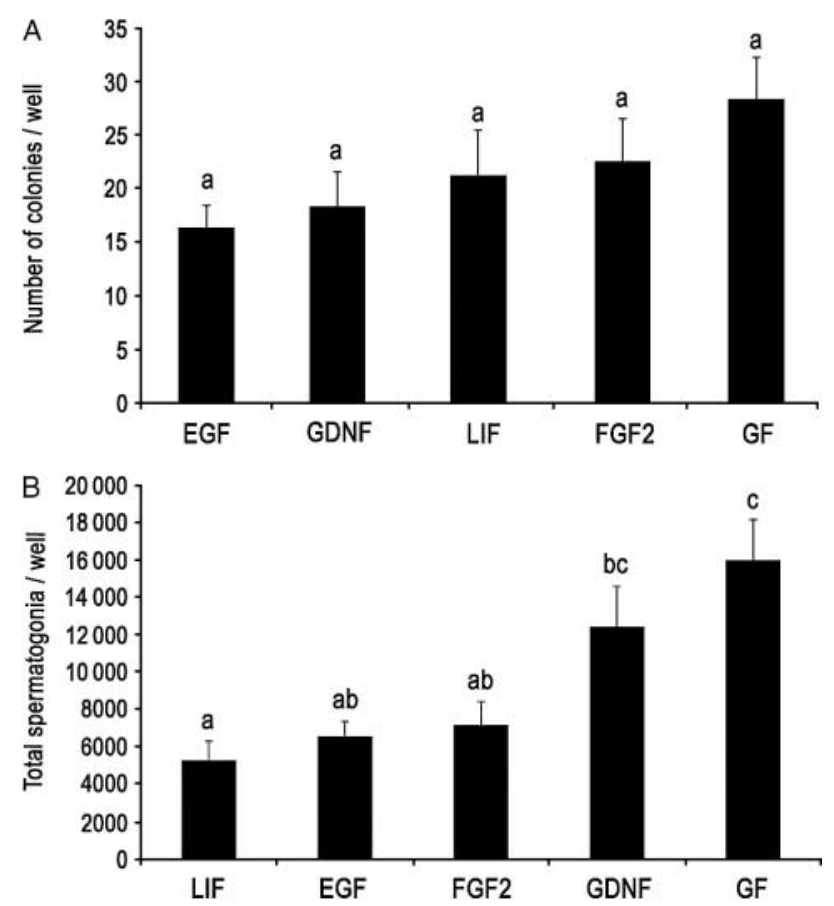

Figure 7 Comparison of the effect of several growth factors (GDNF, LIF, EGF, FGF2 and their combination) on the formation of colonies in bovine spermatogonial cultures. (A) Number of colonies per $2 \mathrm{~cm}^{2}$ well after 15 days of culture. (B) Absolute number of DBA positive, bovine type A spermatogonia, in colonies as estimated by stereological methods. Different superscripts represent significant differences between culture conditions. The results are presented as the mean \pm S.E.M. of three independent experiments.

In this specific culture experiment, from the starting cell suspension, 100000 cells were transplanted to each mouse testis, 70000 of which were type A spermatogonia. After 2 months, about 253 bovine type A spermatogonia were found per transplanted testis. This means that the SSCs present in the transplanted cell suspension had given rise to a number of colonies that in total had formed on the average 253 type A spermatogonia per transplanted testis.

At the end of the culture period (day 30), a cell suspension was obtained of which also 100000 cells were transplanted into each mouse testis. In this case, the purity of the type A spermatogonia was $12.74 \%$ purity (\% of DBA-positive cells) and hence 12740 type A spermatogonia were transplanted per recipient mouse testis. Two months after transplantation, per recipient mouse testis, 366 type A spermatogonia were counted. These data indicated that there was a higher proportion of SSCs among the cultured type A spermatogonia than among the type A spermatogonia of the starting cell population. The difference could be calculated to be $366 / 12740$ divided by $253 / 70000=8$-fold. In addition, we had to take into account that at each passage of the cultures the cells were considerably diluted. At each passage, a small aliquot of cells was replated and the rest taken out of the experiment. If the discarded cells had also been cultured, the total number of SSCs at the end of culture would be higher, in proportion to the total dilution factor. At the start of the experiments, 36500 type A spermatogonia were put in the culture; and at the end of the culture, 680000 type A spermatogonia were harvested. Taking into account the dilution $(2 \times 2 \times 4 \times$ $2 \times 2 \times 1.5=96$ ), the culture during 30 days rendered a 1780 -fold increase in type A spermatogonial numbers. The fold increase of SSCs during culture was then calculated as the increase in the purity of SSCs (eightfold) multiplied by the increase in type A spermatogonial numbers (1780-fold) is 14240 -fold.

\section{Discussion}

Transgenesis technologies were first developed in laboratory animals. Recently, interest arose in the possibilities to use the male germline to create transgenic animals. One key point to advance in this important aspect of stem cell research is the acquisition of large enough quantities of SSCs. The possibility to propagate these cells in vitro would be very helpful in this respect, especially considering the low numbers of SSCs presents in the testis, about $0.03 \%$ of all germ cells in the mouse (Tegelenbosch \& de Rooij 1993), and the small testicular samples that will most likely become available in genetically valuable large animals.

In the present study, we successfully propagated bovine SSCs in the culture using a stem cell specific medium and tested the effects of several growth factors. We used a highly enriched medium, originally used by Kanatsu-Shinohara et al. (2003b) to stimulate proliferation of SSCs in cultures of mouse spermatogonia. Comparing this medium to our routinely used supplemented MEM cell culture medium, we found that the stem cell medium outperformed supplemented MEM in terms of number of colonies arising during culture and total numbers of bovine spermatogonia within the colonies. In addition, the morphology of the colonies was very much different in that a complex arrangement of somatic and germ cells was observed.

In a previous paper, the colonies were defined as clusters of type A spermatogonia of at least 64 cells (Aponte et al. 2006). Interestingly, with the present culture conditions, the colonies evolved to a higher level of organization and consisted of a dense core of cells including spermatogonia, intermingled with somatic cells. The colonies at this degree of development were difficult to characterize because of the tight arrangement of the constituent cells. Therefore, we sectioned the colonies to get a clearer picture of their internal structure. The morphology of the colonies that were formed in the stem cell medium included densely packed somatic cell areas surrounding round distinct, flat somatic cells lined, less dense areas, inside which spermatogonia were always located. 

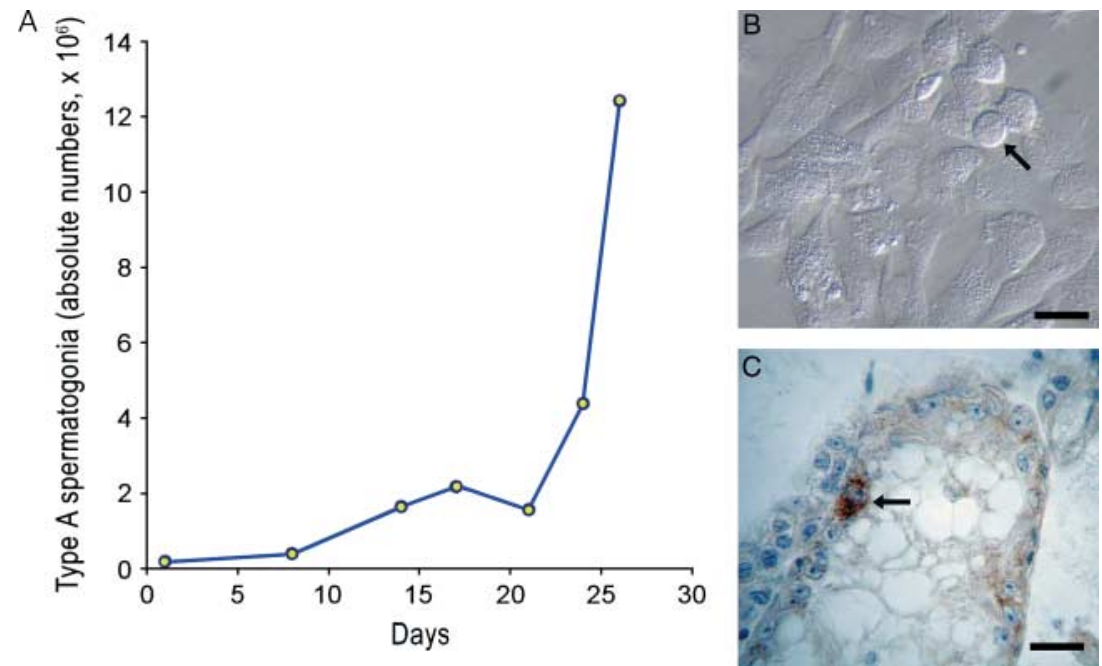

Figure 8 Expansion of the type A spermatogonia population on long-term culture and identification of SSCs. (A) Expansion of the population of type A spermatogonia during a first experiment of 26-day culture with stem cell medium and the combination of four growth factors (GDNF, LIF, EGF, and FGF2). At each time point (passage), the total number of cells was estimated with a hemocytometer and corrected for viability and DBA-positive cells percentage (smears were prepared that were stained for DBA to determine the purity of the type A spermatogonia), see Materials and Methods. A total expansion of type A in this experiment was 365-fold. (B) Cell with the typical morphology of type A spermatogonia (arrow) laying on top of a somatic cell monolayer after the last of several passages during a culture experiment of 30 days, established to test the expansion of SSCs. A total expansion of the type A spermatogonial population in this experiment was 1780 -fold. These cells were marked with DBA in sample smears to estimate their numbers at different time points (staining not shown, see Materials and Methods). Nomarski optics. Bar $=10 \mu \mathrm{m}$. (C) Type A spermatogonium (arrow) present in the basal compartment of a seminiferous tubule of a nude mouse 2 months after transplantation and originally obtained from a 30-day serial subculture. In all cases, the bovine type A spermatogonial marker was DBA (brown). Counterstaining with Mayer's hematoxylin stained the nuclei of the cells (blue). Bar $=10 \mu \mathrm{m}$.

Apparently, the growth factors and other components of the stem cell medium induced the formation of organized structures in vitro. The fact that no round areas were found, which did not contain spermatogonia with or without any of the growth factors, indicates that the formation of these structures depends on the presence of germ cells. The spherical colonies do not seem to originate from aggregation of detached cells during monolayer formation but likely self-generate during early monolayer formation. Apparently, spermatogonia interact with some somatic cells that do not join the ongoing monolayer formation, in such a way that the somatic cells contact, intermingle, and surround them resembling what happens during testis chord formation during fetal development. One part of the mechanism of colony formation may involve the cytoplasmic extensions of somatic cells that contact germ cells during the early stages of colony formation. These contacts may trigger the formation of a conglomerate that will become a spherical colony, while leaving a connection or stalk with the monolayer made up of a narrow bundle of somatic cells.

Once inside the colonies, the germ cells seem to be compartmentalized by surrounding flat somatic cells. In parallel, the somatic cells continue to proliferate, increasing the size of the colonies by depositing layers of peritubular myoid and some Sertoli cells toward the outskirts, also showing proliferative activity as evidenced by mitotic figures.
At first glance, many of the cells inside the colonies morphologically resemble somatic cells of testicular origin. Interestingly, the cells surrounding the round areas inside the colonies were very similar to the peritubular myoid cells seen in vivo. As Sertoli cells are present as contaminants in bovine type A spermatogonia suspensions in a range of $20-50 \%$ (Izadyar et al. 2003a, Aponte et al. 2006), these cells also contribute to the somatic components of the colonies. Immunohistochemistry using a Sertoli cell marker (vimentin) and a peritubular myoid cell marker $(\alpha-S M A)$ revealed that peritubular myoid cells together with Sertoli cells participated in the formation of a 'capsule' in the periphery of the colony. Furthermore, both cell types appear scattered in the core of the colony, not showing a preferred location with respect to the round areas containing germ cells. However, Sertoli cells are more abundant. Surprisingly, the flat cells surrounding the round areas are mainly Sertoli cells and not peritubular myoid cells. The change of the morphology of some Sertoli cells to a flattened phenotype is probably due to unknown responses to components in the stem cell medium. Interestingly, spermatogonia inside the round areas of the colonies are in close vicinity to Sertoli cells but the cytoarchitecture is not the typical one of a seminiferous tubule, as germ and Sertoli cells appear randomly arranged in the colonies. Apparently and despite the richness of the culture medium used, it was not possible to trigger the formation of true seminiferous 
tubules in the same manner as was achieved when transplanting a testicular cell suspension of pig origin into the mouse s.c. tissue (Honaramooz et al. 2007). However imperfect, the patterns observed in our study still show an interesting morphogenic rearrangement of somatic and germ cells in vitro to form a well-defined and organized structure. Future work will hopefully lead to conditions allowing the formation of de novo seminiferous tubules in vitro.

The contamination of the stem cell cultures with Leydig cells was very low. The expression of the marker enzyme $3 \beta-$ HSD type 1 in Leydig cells is not dependent on the presence of luteinizing hormone (LH). Even in the continuous absence of $\mathrm{LH}$ signaling, in $\mathrm{LH}$ receptor knockout mice, it is possible up to adulthood to detect $3 \beta$ HSD type 1 immunoreactivity in Leydig cells (Zhang et al. 2004). Although Leydig cell progenitors and immature Leydig cells can survive in culture for several weeks up to months, even in the absence of LH (Teerds, de Boer and Rommerts unpublished observations), the proliferative activity of these cells is negligible (Teerds et al. 2007), nor do these Leydig cells produce measurable amounts of testosterone. Thus, even though low numbers of Leydig cells may be present in the stem cell cultures, it is highly unlikely that these cells will somehow affect the stem cells under the present conditions. Other cell types were not characterized, but might include endothelial cells and fibroblasts. As $\alpha$-SMA seems to stain some endothelial cells, the number of myoid peritubular cells in the cultures might appear lower than expected. This has been shown to be a specific pattern of staining for bovine species (Devkota et al. 2006).

The growth factors used in our experiments are quite generally used in male germline stem cell cultures, including SSCs. In the present study, we have attempted to learn more about their individual effects. Histological sections of the colonies arising in the stem cell medium to which LIF, GDNF, FGF2, EGF, or a combination of the four growth factors was added, in principle all showed the described morphology. Often, the dead cells with pycnotic nuclei were intermingled with healthy spermatogonia inside the round areas, especially in LIF colonies. Probably, with this growth factor, the surrounding somatic cell layers become a barrier for some nutrients. Interestingly, GDNF alone or in combination with the three other growth factors induced the formation of colonies in which the round areas were preferentially located at the outskirts, with only a very thin somatic cell layer separating them from the culture medium. This is in accordance with our previous report showing that GDNF induced the presence of a higher number of type A spermatogonia at the periphery of intact (not-sectioned) bovine colonies in culture (Aponte et al. 2006). Davis \& Schuetz (1977) and Davis (1978) cultured cells dissociated from the testes of 15-day-old rats and obtained monolayers supposedly consisting of Sertoli cells, in which vesicle-like structures were found as well as tubes that arose by rolling of the cells at the edges of the monolayer. These structures are not comparable with those we found in our cultures in which germ cells did stay present. In another study on mouse SSCs, a different set of growth factors was used (LIF, FGF2, kit ligand, platelet derived growth factor, and insulin-like growth factor-1) than in the present study but an increase in the rate of proliferation inside the colonies was found (Jeong et al. 2003). In both systems (bovine and mouse), the colonies appeared with a similar timing, that is, around 7 days of culture. Noteworthy, the combination of growth factors used in the mouse cultures did not include GDNF. Differences in the stimulatory effect of different groups of growth factors might be related to the nature of the starting cell population (i.e., age, species, cell density, and somatic cell contamination).

In general, colonies tended to be spherical in shape. However, the use of additional growth factors (LIF, GDNF FGF2, EGF, or a combination of all four) induced differences in the morphology of the colonies. For instance, under the influence of EGF and FGF2, big odd-shaped colonies appeared. Stereological analysis of the colonies indicated that although EGF has been described as a spermatogonial growth factor (WahabWahlgren et al. 2003, Anjamrooz et al. 2006), the cultures with this growth factor showed the largest volume of somatic cells. In EGF-treated cultures, spherical colonies arose interconnected by bridges. Whether separate spherical colonies merge with one another through somatic cell proliferation or start as one colony and sprout to make new spherical daughter colonies in rows connected by somatic cell bridges remains to be studied. The origin of these bridges may lie in the cytoplasmic extensions of peripherically located somatic cells in one colony connecting with other germ cells that are in the process of forming a separate colony nearby. While this second spherical colony forms, it probably remains connected to the first one through what will be a 'bridge' later in the process. We have seen these very long cytoplasmic processes trying to connect with germ cells in early stages of the cultures, but cannot definitely relate this complex cell to cell interaction with the process of bridge formation between colonies. The effect of EGF may be direct on somatic cells (Leydig cells, Sertoli cells, and peritubular myoid cells) as well as spermatogonia as both express EGF receptors in rats (Wahab-Wahlgren et al. 2003). In bulls, in the seminiferous epithelium, the EGF receptor is restricted to germ cells, but it is also present in the somatic cells of the straight tubules and rete testis (Kassab et al. 2007).

In our bovine culture system, FGF2 produced large elongated colonies with an abundance of somatic cells with the morphology of Sertoli cells. In rats, the FGF2 receptor has been traced to several somatic cell types (Sertoli cells, Leydig cells, and myoid peritubular cells; Le Magueresse-Battistoni et al. 1994, El Ramy 
et al. 2005). Indeed, FGF2 has been associated with promoting both the proliferation and survival of somatic cells in vitro (Han et al. 1993, Van Dissel-Emiliani et al. 1996, Steger et al. 1998). Interestingly, Van DisselEmiliani et al. (1996) also found an effect of FGF2 on culture morphology as they observed the formation of groups of tightly packed Sertoli cells in cocultures of rat Sertoli cells and gonocytes. The relatively small size of LIF colonies in our experiments might be related to the fact that at least in rats, the receptor is limited to the spermatogonial population (Dorval-Coiffec et al. 2005).

When a combination of all growth factors was used, big colonies of mixed characteristics appeared. Since DBA-positive cells were very abundant inside broad round areas, these complex colonies seem to support spermatogonia most effectively. Immunohistochemical staining for DBA allowed us to identify type A spermatogonia in the colonies (Ertl \& Wrobel 1992, Izadyar et al. 2002a). Our finding that the medium including all four growth factors was superior with respect to the numbers of spermatogonia formed is consistent with previous results indicating that a combination of growth factors can induce self-renewal of SSC in vitro (Kanatsu-Shinohara et al. 2003b, 2005, Kubota et al. 2004b). GDNF-only treatment came second with respect to spermatogonial numbers, which provided further evidence that, as in the mouse (Meng et al. 2000, Kanatsu-Shinohara et al. 2003b, Kubota et al. 2004a, 2004b), GDNF has an important role in bovine SSC self-renewal physiology. Remarkably, spermatogonia had a healthy appearance (i.e., normal size of about 10-12 $\mu \mathrm{m}$ diameter, round nucleus with usually one large nucleolus and no morphological signs of apoptosis) when cultured with GDNF as well as the combination of the four growth factors (including GDNF). Germ cells were very rarely seen outside of the colonies; hence spermatogonia apparently do not survive outside of the colonies for periods as long as 15 days. Furthermore, the highest numbers of spermatogonia were found with conditions allowing the formation of the most welldeveloped colonies. In view of the steep increase in spermatogonial numbers with culture time, the increase in spermatogonial numbers is very likely associated with increased proliferation. This has also been shown in SSC colonies in the mouse (Jeong et al. 2003).

Apparently, the initial SSCs in our culture were surrounded by somatic cells to form a colony and were able to self-renew under the influence of the combination of growth factors. At a comparable time point (day 14) in two different type of experiments (short versus long term), there were around seven times more type A spermatogonia in cultures that involved passaging than in those left undisturbed for 15 days. Without subculturing some expansion of the type A spermatogonial population did occur, but the increase was definitely more important in the long-term approach which included frequent passaging. Enzymatic dissociation of the cultured cells at every passage probably opens new niche sites in the cultures inducing SSCs to self-renew. The type A spermatogonial population grew during long-term culture experiments of 26 and 30 days of duration. The growth was superior in the 30-day culture (1780-fold) than in the 26-day culture (365-fold) probably because in the first case the cells, besides having more time to proliferate, had been frozen, in contrast with the second case, in which freshly isolated cells were used. In this respect, Kanatsu-Shinohara et al. (2003a) suggested that a possible mechanism of positive selection of SSCs related to the freezing procedure. In parallel, the growth factors used also affected the somatic cell population which increased in size as observed in the shift of the germ cell:somatic cell ratio during culture. The detailed nature of these effects will require further investigations.

Upon transplantation of the cultured cells, colonization of the recipient mouse testes was found, implying that at least some of the cultured type A spermatogonia were SSCs that were able to migrate to the basal membrane of the tubules and did retain their stem cell properties. Although transplanted bovine SSCs did not give rise to colonies with full spermatogenesis in mouse seminiferous tubules, these cells did proliferate and colonized the recipient mouse testis with type A spermatogonia, as described previously (Izadyar et al. 2003a). The numbers of type A spermatogonia present 2 months after transplantation (DBA-positive cells) were taken as a measure of the numbers of stem cells transplanted. In our experiments, almost all bovine DBA-positive cells sitting on the basal membrane of the mouse seminiferous tubules 2 months after transplantation were single cells. This has also been observed by others (Dobrinski et al. 2000, Zhang et al. 2008). The duration of spermatogenesis in the bull being 61 days, after 2 months any non-stem germ cell 'contaminants' of the original transplanted cell suspension will have had enough time to undergo the whole spermatogenic process, if capable of this, and will have been shed as sperm. Therefore, the bovine type A spermatogonia, as detected by DBA staining, in the recipient mouse testes are daughter cells of transplanted stem cells and, as already discussed, their numbers can be expected to be proportional to the number of stem cells transplanted. The results of our transplantation experiment strongly suggest that our culture conditions allowed the in vitro propagation of SSCs. A more than 14000 -fold increase in SSC number was found after 30 days of culture, indicating that our culture system has the capacity to expand the SSC population.

It would be interesting to study the ability of bovine SSCs to repopulate a recipient bovine testis and to give rise to full spermatogenesis. Important advances in this respect have been achieved in ruminants. In goats, full spermatogenesis and derived offspring has been obtained from transplanted germline cells (Honaramooz 
et al. 2003a, 2003b). However, in bulls, colonization and full spermatogenesis has been achieved only after autologous transplantation of SSCs (Izadyar et al. 2003b). After homologous and heterologous transplantations, full spermatogenesis has not been shown (Izadyar et al. 2003b, Herrid et al. 2006), probably because stem cells might not survive to an immunological reaction against them, so no or few daughter cells are formed.

Our cell suspensions, transplanted into nude mouse testes, contained somatic cells besides type A spermatogonia. The somatic cell component of the cell suspensions will require further investigation as these cells possess receptors for the growth factors used (Le Magueresse-Battistoni et al. 1994, Wahab-Wahlgren et al. 2003, Dorval-Coiffec et al. 2005, El Ramy et al. 2005, Kassab et al. 2007). It will be interesting to study the prevalence of the different somatic cell types under the action of the different growth factors and the effect of specific somatic cell types on the homing process of bovine SSCs in the mouse seminiferous tubule environment. In this respect, it has recently been shown that bovine DBA-positive cells can colonize mouse seminiferous tubules and survive for 2.5 months supported by cotransplanted bovine Sertoli cells (Zhang et al. 2008).

In conclusion, it is possible to long-term culture SSCs from bovine calf testes. In culture, these SSCs were found to quickly increase in number while retaining their stem cell properties. While our previous results also pointed in this direction, the use of a specific stem cell medium greatly improved the efficiency of the system. It will now be possible to efficiently acquire large numbers of bovine SSCs in a way comparable with that for mouse SSCs and probably to establish bovine cell lines comparable with the germline stem cells available for the mouse (KanatsuShinohara et al. 2003b, 2004). This will open the way to carrying out detailed research on bovine SSCs, possibly leading to applications important for the cattle industry like the production of transgenic animals by transfection of SSCs and transplantation to recipient bull calves.

\section{Materials and Methods \\ Cell isolation and purification}

Testes were collected from calves between 4 and 6 months of age at a commercial slaughterhouse. Isolation was performed as described previously (Izadyar et al. 2002a, 2003a, Aponte et al. 2006). Briefly, about $20 \mathrm{~g}$ testis material was minced into small pieces and suspended in MEM (Gibco, Invitrogen Corporation) supplemented with $0.1275 \% \mathrm{w} / \mathrm{v} \mathrm{NaHCO}_{3}$ (Sigma), $4 \mathrm{mM}$ L-glutamine, $0.1 \mathrm{mM}$ single-strength nonessential amino acids, $100 \mathrm{IU} / \mathrm{ml}-100 \mu \mathrm{g} / \mathrm{ml}$ penicillinstreptomycin, $40 \mu \mathrm{g} / \mathrm{ml}$ gentamicin, and $15 \mathrm{mM}$ HEPES (all from Gibco), subsequently referred to as supplemented MEM. The procedure included two enzymatic digestions, filtration, overnight differential plating, and discontinuous Percoll density gradient centrifugation (Izadyar et al. 2002a). Fractions were evaluated under a Nomarski interference microscope and an
Axioskop (Zeiss, Göttingen, Germany) for estimation of the percentage of type A spermatogonia. The fractions consisting of between 50 and $80 \%$ type A spermatogonia were used. The viability of the primary isolated cells was evaluated using LIVE/ DEAD Viability/Cytotoxicity Kit (Molecular Probes, Eugene, OR, USA) and the total number of type A spermatogonia in the suspension was estimated with a hemocytometer.

\section{Short-term culture}

Cells were seeded at a concentration of 100 cells $/ \mu$ l under seven different culture conditions (Table 1). The defined medium used for conditions 2 through 7 was originally used by Kanatsu-Shinohara et al. (2003b). Briefly, the medium consisted of StemPro-34 serum free medium (SFM) (Invitrogen) supplemented with StemPro supplement (Invitrogen), $25 \mu \mathrm{g} / \mathrm{ml}$ insulin, $100 \mu \mathrm{g} / \mathrm{ml}$ transferrin, $60 \mu \mathrm{M}$ putrescine, $30 \mathrm{nM}$ sodium selenite, $6 \mathrm{mg} / \mathrm{ml}$ D-(1)-glucose, $30 \mu \mathrm{g} / \mathrm{ml}$ pyruvic acid, $1 \mu \mathrm{l} / \mathrm{ml}$ DL-lactic acid (Sigma), $5 \mathrm{mg} / \mathrm{ml}$ bovine albumin ImmunO (MP Biochemicals LLC, Solon, OH, USA), $2 \mathrm{mM}$ L-glutamine, $5 \times 10^{-5} \mathrm{M}$ 2-mercaptoethanol, minimal essential medium (MEM) vitamin solution (Invitrogen), MEM nonessential amino acid solution (Invitrogen), $10^{-4} \mathrm{M}$ ascorbic acid, $10 \mu \mathrm{g} / \mathrm{ml}$ D-biotin, $30 \mathrm{ng} / \mathrm{ml} \beta$-estradiol, and $60 \mathrm{ng} / \mathrm{ml}$ progesterone (Sigma). When present, the growth factors were added at the following concentrations: EGF $20 \mathrm{ng} / \mathrm{ml}$, FGF2 $10 \mathrm{ng} / \mathrm{ml}$, LIF $100 \mathrm{ng} / \mathrm{ml}$, and GDNF $40 \mathrm{ng} / \mathrm{ml}$ (all human recombinant from Sigma).

Fetal calf serum (FCS; Invitrogen) was used at a concentration of $2.5 \% \mathrm{v} / \mathrm{v}$ for condition 1 , as in our previous work involving supplemented MEM (Izadyar et al. 2003a, Aponte et al. 2006). For the other conditions, the concentration was $1 \%$ $\mathrm{v} / \mathrm{v}$ (Kanatsu-Shinohara et al. 2003b).

Cells were cultured in 4-well chamber slides of $2 \mathrm{~cm}^{2} /$ well (Lab-Tek, Nalge Nunc Inc., Naperville, IL, USA) at $37^{\circ} \mathrm{C}$, a humidified atmosphere with $5 \% \mathrm{CO}_{2}$, and refreshed twice a week. The colonies were collected at day 15 by pipetting with a manually bended pipette tip under a stereomicroscope (Nikon SMZ800, Tokyo, Japan) and kept on PBS at $4{ }^{\circ} \mathrm{C}$ until fixation.

\section{Histology}

The colonies were fixed in Bouins fluid and kept in ethanol $70 \%$. To avoid loss during histological processing, the colonies were stained with Mayer's hematoxylin (Sigma) for $30 \mathrm{~s}$, transferred to a drop of $0.5 \% \mathrm{w} / \mathrm{v}$ Pronarose LEEO agar (SphaeroQ, Gorinchen, The Netherlands) at $41^{\circ} \mathrm{C}$ over a hot plate and let cool at room

Table 1 Summary of experimental culture conditions.

\begin{tabular}{llcl}
\hline Condition & Medium & $\begin{array}{c}\text { Fetal calf } \\
\text { serum }(\%)\end{array}$ & $\begin{array}{c}\text { Growth } \\
\text { factor }(\mathrm{s})\end{array}$ \\
\hline 1 & Supplemented MEM & 2.5 & - \\
2 & Stem cell medium & 1 & - \\
3 & Stem cell medium & 1 & LIF, EGF, FGF2, GDNF \\
4 & Stem cell medium & 1 & LIF \\
5 & Stem cell medium & 1 & EGF \\
6 & Stem cell medium & 1 & FGF2 \\
7 & Stem cell medium & 1 & GDNF \\
\hline
\end{tabular}


temperature before placing the specimen in biopsy embedding cassettes (Adamas Instruments, Leersum, The Netherlands) to be further histologically processed. The samples were embedded in paraffin and the colonies were serially sectioned.

\section{Immunohistochemistry}

Type A spermatogonia were identified through DBA immunohistochemistry, as described by Ertl \& Wrobel (1992) and Izadyar et al. (2002a). Briefly, the sections were rehydrated, treated with $3 \% \mathrm{v} / \mathrm{v} \mathrm{H}_{2} \mathrm{O}_{2}$ (Sigma) for $10 \mathrm{~min}$ in the dark to inhibit endogenous peroxidase, and rinsed in PBS. Unspecificsite blocking was done with 5\% w/v BSA in PBS for 15 min and then sections were washed with HEPES buffer ( $1 \% \mathrm{v} / \mathrm{v}$ HEPES buffer, Invitrogen, $0.1 \mathrm{M} \mathrm{NaCl}$ in distilled water). Subsequently, the samples were incubated with biotinylated DBA (Vector Laboratories, Inc., Burlingame, CA, USA) at 1:500 in HEPES for $1 \mathrm{~h}$ at $37^{\circ} \mathrm{C}$ in a moist chamber. After incubation with DBA, the samples were rinsed with HEPES and washed three times in PBS. The horseradish peroxidase-biotin complex reaction was performed using an ABC Kit (Vector Laboratories), 1:500 each in PBS. Lectin binding was visualized using $25 \mathrm{mg}$ of 3,3'diaminobenzidine tetrahydrochloride (DAB; Sigma), as chromogen substrate, and $17 \mathrm{ml}$ of $35 \% \mathrm{v} / \mathrm{v} \mathrm{H}_{2} \mathrm{O}_{2}$ per $50 \mathrm{ml}$ in PBS for $1 \mathrm{~min}$. The samples were rinsed thoroughly in distilled water, counterstained with hematoxylin (Sigma), dehydrated in graded alcohols, cleared in xylol, and mounted in Pertex (Histolab, Göteborg, Sweden). Negative control sections were incubated in $1 \% \mathrm{w} / \mathrm{v}$ BSA in PBS without lectin.

Vimentin immunostaining was carried out in order to identify Sertoli cells. After deparaffination and rehydration, endogenous peroxidase was inhibited, samples washed with PBS, and treated with Triton X-100 (Sigma-Aldrich) at $0.5 \% \mathrm{v} / \mathrm{v}$ for $30 \mathrm{~min}$. Unspecific-site blocking was done with Normal Goat Serum (Vector Laboratories). The first antibody was mouse antivimentin and non-hematopoietic (Biogenex, San Ramon, CA, USA) at concentration 1:50. The second antibody was immunoglobulin $M$ (IgM) anti-mouse (Vector Laboratories). ABC and DAB steps were done as described for the DBA immunostaining. All inter-step PBS washes, except those after ABC treatment, were followed by a simple wash with $0.1 \%$ Tween (MerckSchuchard) in PBS as well as the blocking and antibody steps.

Similarly, $\alpha$-SMA immunostaining was performed to identify myoid peritubular cells. A pretreatment was done with Triton X-100 $0.4 \%$ for 10 min (Sigma). Blockage was with Normal Horse Serum 5\% v/v (Vector Laboratories) for $1 \mathrm{~h}$ at room temperature. The first antibody was anti- $\alpha-S M A$ Mu-128 (Biogenex) $1: 500$, in $1 \% \mathrm{w} / \mathrm{v} \mathrm{BSA}$ in PBS, at $4{ }^{\circ} \mathrm{C}$, overnight. The second antibody was IgM anti-mouse (Vector Laboratories), $1: 200$, in $1 \%$ BSA in PBS at room temperature. The rest of the procedure was as in DBA and vimentin immunostaining.

Staining $3 \beta-H S D$ type 1 was performed as described by Teerds et al. (1999). Briefly, the sections were incubated overnight at $4{ }^{\circ} \mathrm{C}$ with a polyclonal anti-3 $\beta$-HSD type 1 antibody raised in goat (Santa Cruz, (C-18, SC-30821), Santa Cruz, CA, USA) diluted 1:300 in TBS + BSA-c (Aurion, Wageningen, The Netherlands). This was followed by five washes with TBS and incubation with a biotinylated secondary rabbit-anti-goat antibody (Vector Laboratories) diluted 1:200 in TBS+BSA-c for $1 \mathrm{~h}$ at room temperature.
Slides were again washed with TBS and incubated for $60 \mathrm{~min}$ with the components avidin (A) and biotin (B) of the ABC staining kit elite (Vector Laboratories) diluted 1:1500 in TBS+BSA-c. Bound antibody was visualized using $0.6 \mathrm{mg} / \mathrm{ml}$ solution of 3,3'diaminobenzidin in TBS to which $0.03 \% \mathrm{H}_{2} \mathrm{O}_{2}$ was added. The slides were counterstained with Mayer's hematoxylin. In the control experiments, the first antibody was replaced by normal goat serum. No background staining was observed (not shown).

\section{Stereology}

Volume, density (or cells per volume unit), and absolute numbers of DBA-positive cells (spermatogonia) in both colonies and transplanted testes were estimated through unbiased stereological methods. For this purpose, one in every tenth $5 \mu \mathrm{m}$ thick sections was used (with a random sectioning start). Colony volumes were estimated by the Cavalieri method (Howard \& Reed 1998), by adding the several sub-volumes constituting the colony. Each sub-volume was defined as the product of the area of the colony profile in the section by the distance to the next section analyzed, that is the area of the profile of the colony $\times 5 \mu \mathrm{m}$, which is the section thickness $\times 10$, or the number of sections in between samples (in summary, profile area $\times 50 \mu \mathrm{m}$ ). The areas of the profiles of the colonies were measured using the Image 1.34S program, developed by Dr W Rasband at the National Institute of Health, Bethesda, USA, and downloaded from the Internet at http://rsb.info.nih.gov/ij/, previously applying the appropriate calibration.

Spermatogonial density (spermatogonia per volume unit) is a required input to calculate the absolute numbers of these cells. It was estimated using a stereological method: the physical disector. For this, colony images from serial consecutive pairs of sections (a consecutive pair taken every tenth section with a random start in the series) were digitalized. The image pairs were exposed simultaneously side by side on a wide computer screen and square-shaped counting frames were randomly generated and positioned in the same corresponding area in both images with the help of software developed by $\operatorname{Dr} M$ Terlou, Department of Biology, Utrecht University, The Netherlands. DBA-positive cells that appeared in the first image (called reference section) but had disappeared in the same area in the second section (look-up section) were counted. Whenever a DBA-positive cell appeared in both sections, it was not included in the counting (Howard \& Reed 1998). The area of the counting frame was recorded and used to calculate the sample volume to refer to the counting. This volume was equal to the counting frame area times the length of the space between the consecutive pair of sections $(5 \mu \mathrm{m})$. The division of the reference volume by the counted DBA-positive cells yielded figures of density, i.e. number of spermatogonia per volume unit (spermatogonia/ $/ \mathrm{m}^{3}$ ). Absolute numbers of spermatogonia were estimated by the product of the volume of the colony (estimated through the Cavalieri method, as previously described) times the spermatogonial density, that is, colony volume $\left(\mu \mathrm{m}^{3}\right) \times$ density $\left(\right.$ spermatogonia/ $\left.\mu \mathrm{m}^{3}\right)$. Absolute numbers of spermatogonia per colony were multiplied by the number of colonies in each well to obtain the number of spermatogonia per well. 


\section{Long-term culture}

The cells were seeded at 50 cells/ $\mu$ l on 6 -well dishes (Lab-Tek, Nalge Nunc Int.) with stem cell medium, 1\% v/v FCS, and growth factors (EGF, FGF2, LIF, and GDNF at concentrations specified elsewhere) during 26-30 days, during which the cells were subcultured six to seven times. The cells (germ and somatic cells) were separated through enzymatic digestion and gentle pipetting. The cells were cultured in culture dishes in which the medium was bathing the cells from above. The cultures were refreshed twice a week with the corresponding growth factors, and passaged 1:2 to 1:4 every 3-5 days, depending on the rate of somatic cell proliferation. The cells had to be passaged just before $100 \%$ confluency to avoid contact inhibition and subsequent detachment of the monolayer from the culture plate. Whenever detected incidental foldings or pealing off the monolayer, mainly during early pilot experiments, we aborted the cultures and started all over again.

\section{Type A spermatogonia quantification during 26-day culture}

The number of type A spermatogonia at different time points during culture could be estimated through the formula: Type A number $=$ Total number of cells $\times$ Type A purity. At every passage, the total number of cells was estimated with the aid of a hemocytometer and the purity of type A spermatogonia (\%) was determined in smears of the cells that previously underwent DBA staining. This culture was started with freshly isolated cells.

\section{SSC transplantation}

The cells were frozen at day 0 (directly from a primary cell isolation) and day 30 (end of serial subculture) to be thawed on the day of transplantation. Freezing and thawing protocols for bovine spermatogonia have been described previously (Izadyar et al. 2002b). The cells from each of the two experimental groups $(n=3)$ were transplanted into irradiated NMRI nude mouse (NU/NU, Harlan, Horst, The Netherlands) testes (5000 cells $/ \mu \mathrm{l}$ or $10^{5}$ cells in $20 \mu \mathrm{l}$ cell suspension per transplanted testis) for SSC functional testing as described previously (Creemers et al. 2002, Izadyar et al. 2003a). The mice were killed after 2 months and the testes collected for histological processing. DBA staining was carried out to evaluate the presence of bovine type $A$ spermatogonia in the recipient mouse testes. DBA-positive cells were counted in an unbiased way in serial sections using the disector method (Howard \& Reed 1998).

The experimental protocol of this experiment followed the Guidelines for the Care and Use of Laboratory Animals and was approved by the Animal Care and Use Committee of the Utrecht University.

\section{Estimation of SSC propagation}

Using DBA immunohistochemistry, the numbers of type A spermatogonia in the starting germ cell population and in the suspensions of germ cells after culture were estimated and about similar numbers of cells (100 000) with known contents of type A spermatogonia were transplanted into each recipient mouse testis. Two months after transplantation, the numbers of bovine type A spermatogonia in the recipient mouse testes were estimated using unbiased stereological methods (see section Stereology). Subsequently, the dilution factor of the cultured type A spermatogonia was calculated as these cells went through multiple passages in which they were diluted. Knowing these data, the fold increase in SSC numbers after culture could be calculated, as described.

\section{Statistical analysis}

General statistical analysis was performed using the independent samples Student's t-test or one-way ANOVA. Multiple comparisons were performed by means of Bonferroni post hoc test. Results are presented as the mean \pm s.E.M. All calculations were performed using the software SPSS for Windows v11.5 (Chicago, Illinois, USA).

\section{Declaration of interest}

The authors declare that there is no conflict of interest that could be perceived as prejudicing the impartiality of the research reported.

\section{Funding}

Grant support: This work was supported in the framework of the EUROSTELLS program of the European Science Foundation (ESF) through ZonMw - The Netherlands Organization for Health Research and Development, and the Council for Scientific and Humanistic Development $(\mathrm{CDCH})$ from the Central University of Venezuela (UCV). T S was supported by a grant from the Uehara Memorial Foundation (Japan) and the Toyobo Biotechnology Foundation (Japan).

\section{Acknowledgements}

We are very grateful for the collaboration from the people at the slaughterhouse B V Export Slachterij Apeldoorn, ESA, Alpuro Group, Apeldoorn, The Netherlands. We also thank Dr Maarten Terlou for kindly designing and providing the specialized software for stereological analysis.

\section{References}

Anjamrooz SH, Movahedin M, Tiraihi T \& Mowla SJ 2006 In vitro effects of epidermal growth factor, follicle stimulating hormone and testosterone on mouse spermatogonial cell colony formation. Reproduction, Fertility, and Development 18 709-720.

Aponte PM, van Bragt MP, de Rooij DG \& van Pelt AM 2005 Spermatogonial stem cells: characteristics and experimental possibilities. Acta Pathologica, Microbiologica, et Immunologica Scandinavica 113 727-742.

Aponte PM, Soda T, van de Kant HJ \& de Rooij DG 2006 Basic features of bovine spermatogonial culture and effects of glial cell line-derived neurotrophic factor. Theriogenology 65 1828-1847.

van Beek ME, Meistrich ML \& de Rooij DG 1990 Probability of selfrenewing divisions of spermatogonial stem cells in colonies, formed after fission neutron irradiation. Cell and Tissue Kinetics 23 1-16. 
Brinster RL \& Avarbock MR 1994 Germline transmission of donor haplotype following spermatogonial transplantation. PNAS 91 11303-11307.

Brinster RL \& Zimmermann JW 1994 Spermatogenesis following male germ-cell transplantation. PNAS 91 11298-11302.

Creemers LB, Meng X, den Ouden K, van Pelt AM, Izadyar F, Santoro M, Sariola H \& de Rooij DG 2002 Transplantation of germ cells from glial cell line-derived neurotrophic factor-overexpressing mice to host testes depleted of endogenous spermatogenesis by fractionated irradiation. Biology of Reproduction 66 1579-1584.

Davis JC 1978 Morphogenesis by dissociated immature rat testicular cells in primary culture. Journal of Embryology and Experimental Morphology $4 \mathbf{4}$ 297-302.

Davis JC \& Schuetz AW 1977 Purification of 'colony-forming' cells from immature rat testis. Experimental Cell Research 106 253-260.

Devkota B, Sasaki M, Takahashi K, Matsuzaki S, Matsui M, Haneda S, Takahashi M, Osawa T \& Miyake Y 2006 Postnatal developmental changes in immunohistochemical localization of alpha-smooth muscle actin (SMA) and vimentin in bovine testes. Journal of Reproduction and Development 52 43-49.

Van Dissel-Emiliani FM, De Boer-Brouwer M \& De Rooij DG 1996 Effect of fibroblast growth factor-2 on Sertoli cells and gonocytes in coculture during the perinatal period. Endocrinology 137 647-654.

Dobrinski I, Avarbock MR \& Brinster RL 2000 Germ cell transplantation from large domestic animals into mouse testes. Molecular Reproduction and Development 57 270-279.

Dorval-Coiffec I, Delcros JG, Hakovirta H, Toppari J, Jegou B \& PiquetPellorce C 2005 Identification of the leukemia inhibitory factor cell targets within the rat testis. Biology of Reproduction 72 602-611.

El Ramy R, Verot A, Mazaud S, Odet F, Magre S \& Le MagueresseBattistoni B 2005 Fibroblast growth factor (FGF) 2 and FGF9 mediate mesenchymal-epithelial interactions of peritubular and Sertoli cells in the rat testis. Journal of Endocrinology 187 135-147.

Ertl C \& Wrobel KH 1992 Distribution of sugar residues in the bovine testis during postnatal ontogenesis demonstrated with lectin-horseradish peroxidase conjugates. Histochemistry 97 161-171.

Han IS, Sylvester SR, Kim KH, Schelling ME, Venkateswaran S, Blanckaert VD, McGuinness MP \& Griswold MD 1993 Basic fibroblast growth factor is a testicular germ cell product which may regulate Sertoli cell function. Molecular Endocrinology 7 889-897.

Herrid M, Vignarajan S, Davey R, Dobrinski I \& Hill JR 2006 Successful transplantation of bovine testicular cells to heterologous recipients. Reproduction 132 617-624.

Honaramooz A, Behboodi E, Blash S, Megee SO \& Dobrinski I 2003 a Germ cell transplantation in goats. Molecular Reproduction and Development 64 422-428.

Honaramooz A, Behboodi E, Megee SO, Overton SA, Galantino-Homer H, Echelard Y \& Dobrinski I 2003b Fertility and germline transmission of donor haplotype following germ cell transplantation in immunocompetent goats. Biology of Reproduction 69 1260-1264.

Honaramooz A, Megee SO, Rathi R \& Dobrinski I 2007 Building a testis: formation of functional testis tissue after transplantation of isolated porcine (Sus scrofa) testis cells. Biology of Reproduction 76 43-47.

Howard CV \& Reed MG 1998 Unbiased Stereology. Three-Dimensional Measurement in Microscopy, New York: BIOS Scientific Publishers Limited.

Izadyar F, Spierenberg GT, Creemers LB, den Ouden K \& de Rooij DG $2002 a$ Isolation and purification of type A spermatogonia from the bovine testis. Reproduction 124 85-94.

Izadyar F, Matthijs-Rijsenbilt JJ, den Ouden K, Creemers LB, Woelders H \& de Rooij DG 2002 $b$ Development of a cryopreservation protocol for type A spermatogonia. Journal of Andrology 23 537-545.

Izadyar F, Den Ouden K, Creemers LB, Posthuma G, Parvinen M \& De Rooij DG 2003a Proliferation and differentiation of bovine type A spermatogonia during long-term culture. Biology of Reproduction 68 272-281.

Izadyar F, Den Ouden K, Stout TA, Stout J, Coret J, Lankveld DP, Spoormakers TJ, Colenbrander B, Oldenbroek JK, Van der Ploeg KD et al. $2003 \mathrm{~b}$ Autologous and homologous transplantation of bovine spermatogonial stem cells. Reproduction 126 765-774.

Jeong D, McLean DJ \& Griswold MD 2003 Long-term culture and transplantation of murine testicular germ cells. Journal of Andrology $\mathbf{2 4}$ $661-669$
Kanatsu-Shinohara M, Ogonuki N, Inoue K, Ogura A, Toyokuni S \& Shinohara T2003a Restoration of fertility in infertile mice by transplantation of cryopreserved male germline stem cells. Human Reproduction $\mathbf{1 8}$ 2660-2667.

Kanatsu-Shinohara M, Ogonuki N, Inoue K, Miki H, Ogura A, Toyokuni S \& Shinohara T $2003 b$ Long-term proliferation in culture and germline transmission of mouse male germline stem cells. Biology of Reproduction $69612-616$.

Kanatsu-Shinohara M, Inoue K, Lee J, Yoshimoto M, Ogonuki N, Miki H, Baba S, Kato T, Kazuki Y, Toyokuni S et al. 2004 Generation of pluripotent stem cells from neonatal mouse testis. Cell 119 1001-1012.

Kanatsu-Shinohara M, Miki H, Inoue K, Ogonuki N, Toyokuni S, Ogura A \& Shinohara T 2005 Long-term culture of mouse male germline stem cells under serum-or feeder-free conditions. Biology of Reproduction $\mathbf{7 2}$ 985-991.

Kassab M, Abd-Elmaksoud A \& Ali MA 2007 Localization of the epidermal growth factor (EGF) and epidermal growth factor receptor (EGFR) in the bovine testis. Journal of Molecular Histology 38 207-214.

Kubota H, Avarbock MR \& Brinster RL 2004a Culture conditions and single growth factors affect fate determination of mouse spermatogonial stem cells. Biology of Reproduction 71 722-731.

Kubota H, Avarbock MR \& Brinster RL 2004b Growth factors essential for self-renewal and expansion of mouse spermatogonial stem cells. PNAS 101 16489-16494.

Le Magueresse-Battistoni B, Wolff J, Morera AM \& Benahmed M 1994 Fibroblast growth factor receptor type 1 expression during rat testicular development and its regulation in cultured sertoli cells. Journal of Endocrinology 135 2404-2411.

Meng X, Lindahl M, Hyvonen ME, Parvinen M, de Rooij DG, Hess MW, Raatikainen-Ahokas A, Sainio K, Rauvala H, Lakso M et al. 2000 Regulation of cell fate decision of undifferentiated spermatogonia by GDNF. Science 287 1489-1493.

Oatley JM, Reeves JJ \& McLean DJ 2004 Biological activity of cryopreserved bovine spermatogonial stem cells during in vitro culture. Biology of Reproduction 71 942-947.

Steger K, Tetens F, Seitz J, Grothe C \& Bergmann M 1998 Localization of fibroblast growth factor 2 (FGF-2) protein and the receptors FGFR 1-4 in normal human seminiferous epithelium. Histochemistry and Cell Biology 110 57-62.

Teerds KJ, de Boer-Brouwer M, Dorrington JH, Balvers M \& Ivell R 1999 Identification of markers for precursor and leydig cell differentiation in the adult rat testis following ethane dimethyl sulphonate administration. Biology of Reproduction 60 1437-1445.

Teerds KJ, Rijntjes E, Veldhuizen-Tsoerkan MB, Rommerts FF \& de BoerBrouwer M 2007 The development of rat Leydig cell progenitors in vitro: how essential is luteinising hormone? Journal of Endocrinology 194 579-593.

Tegelenbosch RA \& de Rooij DG 1993 A quantitative study of spermatogonial multiplication and stem cell renewal in the $\mathrm{C} 3 \mathrm{H} / 101$ F1 hybrid mouse. Mutation Research 290 193-200.

Wahab-Wahlgren A, Martinelle N, Holst M, Jahnukainen K, Parvinen M \& Soder O 2003 EGF stimulates rat spermatogonial DNA synthesis in seminiferous tubule segments in vitro. Molecular and Cellular Endocrinology 201 39-46.

Zhang FP, Pakarainen T, Zhu F, Poutanen M \& Huhtaniemi I 2004 Molecular characterization of postnatal development of testicular steroidogenesis in luteinizing hormone receptor knockout mice. Endocrinology 145 1453-1463.

Zhang Z, Hill J, Holland M, Kurihara Y \& Loveland KL 2008 Bovine Sertoli cells colonize and form tubules in murine hosts following transplantation and grafting procedures. Journal of Andrology 29 418-430.

Received 14 September 2007

First decision 30 October 2007

Revised manuscript received 24 July 2008

Accepted 28 July 2008 